\title{
Relationship between the age, the bone density, and the height of mandibular residual ridge in edentulous menopausal women
}

\author{
Helmi Siti Aminah, Muslich Mahmud, Poedji Rahajoeningsih \\ Department of Prosthodontics Faculty of Dentistry Universitas Padjadjaran
}

\begin{abstract}
Good quantity and quality of bones are keys of the success of prosthodontic treatment. The quantity of bones is showed by the height of mandibular residual ridge, whereas the quality of bones is indicated by the bone density. The aim of this study is to investigate the relationship between the age, the bone density, and the height of mandibular residual ridge. The observation is carried out to six edentulous menopausal women. The height of mandibular residual ridge and the mandibular bone density are measured by using CBCT-3D (Cone Beam Computed Tomography-3 Dimension). Pearson analysis of bivariate correlation is used to determine the relation between variables. As a result there is a strong correlation between the increased of the age and the decrease of mandibular bone density $(r=-0.922$ with $\alpha=0.009$ ). The study also shows a significant correlation between the decrease of the height of mandibular residual ridge and the decrease of the mandibular bone density ( $r=0.815$ with $\alpha=0.048$ ), and between the decrease of the height of mandibular residual ridge and the increase of the age $(r=-$ 0.89 with $\alpha=0.017$ ). To summarize, the decrease of the height of mandibular residual ridge in this study correlates with the decrease of the mandibular bone density and the age.
\end{abstract}

Key words: Age, mandibular bone density, height of mandibular residual ridge, edentulous menopausal women

\section{INTRODUCTION}

The life expectancy of Indonesian people has increased from 63.48 years in 1995 to 66.2 years in 2002. ${ }^{1}$ By the increasing life expectancy, diseases related to old age also become more apparent, including osteoporosis. Osteoporosis is a condition showing decreased bone mass without changes in chemical composition. The bone mass compactness is shown through its density. Reduced bone mass occurs when resorption process is not balanced with new bone development process. ${ }^{2}$
In women of menopause age, increased bone resorption happens because of reduced estrogen level. The estrogen deficiency leads to blood calcium homeostatic disorders that causes osteoclasts to resorb bone calcium to fulfill the need for calcium in the blood, leading to reduced bone calcium level. ${ }^{3-5}$ The bone parts that experience reduced density that can be observed radiographically are bones that hold body weight such as spine, hip bone, wrist bone and mandibular bone. $^{2}$

After the age of 40 years, the skeletal bone 
density will be reduced in a way that at the age of 65 years old one third of bone mineral will be missing. Reduced physical activities, low estrogen secretion, diet, race, and heredity play a role in the relationship between age and bone mass loss. Age related bone mass loss is also seen in mandible. During the last 20 years, new advances in imaging have made determination of density easier, not only for the skeletal bone but also for jaw bones. Several studies have concluded that low skeletal bone density has been accepted as a predisposing factor of fast ridge resorption in mandible. The study concludes that skeletal bone mineral loss affect the speed of ridge resorption and jaw bone density. ${ }^{2,6-9}$ However, other studies show contradictive results. ${ }^{11}$ According to Von Wowern, ${ }^{12}$ analysis on the relationship between mandibular bone density and its influence towards mandibular ridge height can only be done to the mandibular bone itself. Therefore, the density examination in other skeletal parts will only give limited conclusion.

In prosthodontic treatment, including partial removable denture, full removable denture, fixed denture, overdenture and, the most sophisticated one, implant denture, the quality and quantity of alveolar bone and its covering mucosa is one of the keys to treatment success. At the moment, osteoporosis has not been an important consideration in making full denture while the female users of full denture are usually in the age group that has high risk for osteoporosis. ${ }^{5}$ In menopause women with low bone density, the skeletal bone strength will be reduced and it will affect the clinical prognosis of prosthodontic treatment. ${ }^{13}$ Patients with osteoporosis will need to change denture more often compared to patients without osteoporosis. ${ }^{14}$

Tallgren ${ }^{15}$ in his studies onedentulous patients who are wearing full denture stated that the ratio of mandibular resorption to maxillary resorption is $4: 1$. The average mandibular resorption is $0.2 \mathrm{~mm}$ per year. This is due to the fact that the contact area between denture and underlying mandibular tissue is three times smaller than that on the maxilla leading to higher average unit pressure in mandible. Despite various variations between individuals, significant reduction of residual ridge continues with time. This has become the main problem for patients who use conventional full denture. This situation often creates less support, retention, stabilization and masticatory functions of the denture.

Wical and Swoope ${ }^{16}$ has found a method for measuring mandibular alveolar bone resorption in edentulous patients using panoramic photo. This method has been used by many researchers to determine resorption level in mandible.

Wical and Swoope ${ }^{16}$ used mental foramen as the landmark to measure the size of resorption in mandible. The radiographic image of mental foramen is recommended as the reference point to measure the amount of alveolar bone loss because the distance between foramen and mandibular lower edge is relatively constant despite the increasing age or alveolar process resorption above the foramen. From the panoramic photo image, the ratio between the distance between mandibular lower edge to mental foramen base and the distance between mandibular lower edge to alveolar highest point is $1: 3$. With this formulation, the size of mandibular resorption can be determined.

Picasso Trio instrument is one of the latest radiographic instruments using CBCT-3D (Cone Beam Computed Tomography-Three Dimension) technology. This instrument has been operated at RSGM FKG UNPAD since early 2007. Picasso Trio can provide information on the size of bone density and image of trabecular and cortical bones with minimum distortion. The radiation dose of this instrument is $6 \times$ lower than the dose in conventional radiograph. ${ }^{17}$

Based on the above description, the author is interested to do a study on the relationship of age, mandibular bone density and mandibular height reduction. The measurement for resorption size is performed using the formulation of Wical and Swoope ${ }^{16}$, while the height and density of the mandibular bone is measured using Picasso Trio instruments. It is expected that this research can give inputs to dentists, especially for the prosthodontic specialists, to prevent severe bone resorption by making appropriate prothesis.

\section{METHODS}

This study is an analytic descriptive survey study. By using CBCT-3D imaging, the mandibular bone of female edentulous patients who visited 
the Prosthodontic Department of RSGM FKG UNPAD was examined. The sampling method used is the purposive sampling where samples were selected by the researcher based on the criteria developed for this study.

The criteria for the study subjects are: (1) Female edentulous patients who are in menopause stage: (2) No systemic disease; (3) No congenital abnormalities; (4) Never use prosthetic denture; (5) Willing to participate as the study subject.

The procedure applied is as follow: (1) Patients are selected using the criteria by filling out an examination form consisting of personal data (name, address, age), general anamnesis
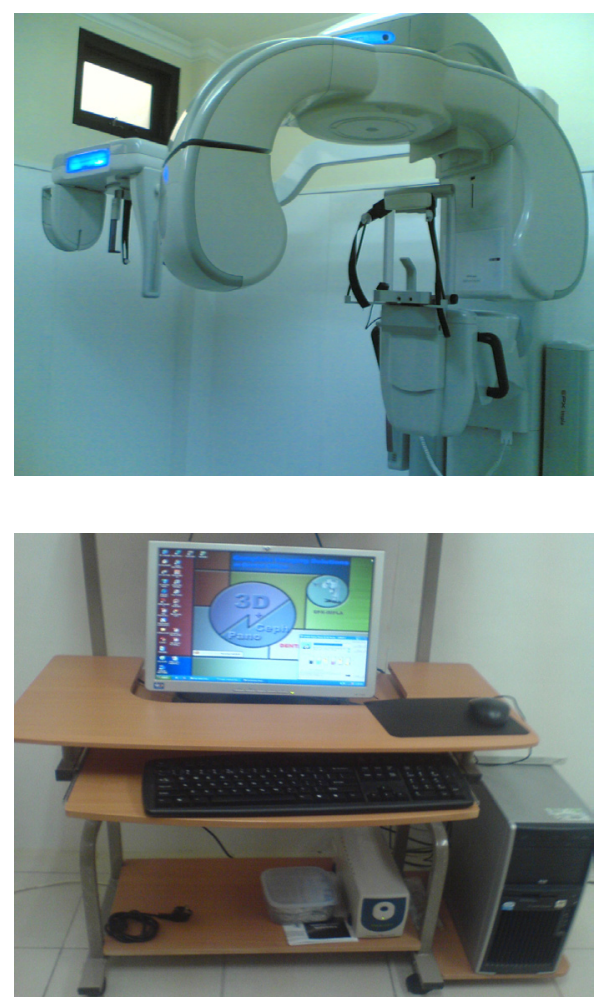

Figure 1. Picasso trio instrument.

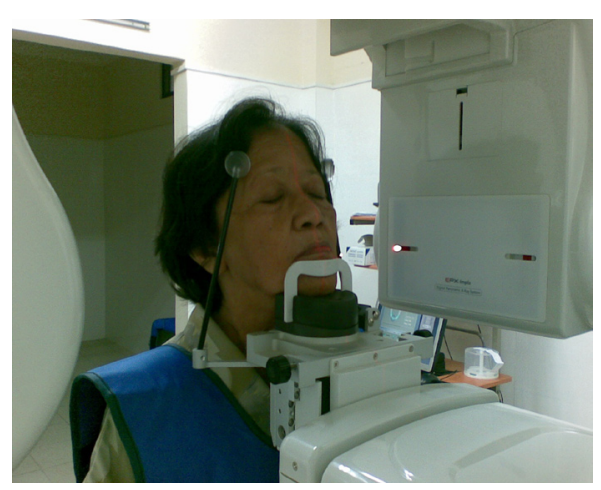

Figure 2. Patient position during imaging. (how long have been in menopause, systemic disease suffered, medicine taken), oral and dental anamnesis (2) Image making using CBCT 3-D technology by Picasso Trio instrument for all subjects. The procedure of CBCT 3-D imaging is as follow: (a) The patient is asked to remove all metal from her body including earrings, glasses and necklace before the procedure; (b) Apron is worn as radiation protector; (c) Night bite dam that has been adapted to the vertical dimension hight and orientation fields is applied and bitten by the patient; (d) The patient is asked to stand/ sit down straight with chin position on chin cup and head is stabilized using headrest; (e) The x-ray tube situated around the head will move around the head for 20 seconds and then stop. During this process, patient's eyes are closed; (f) In 1-2

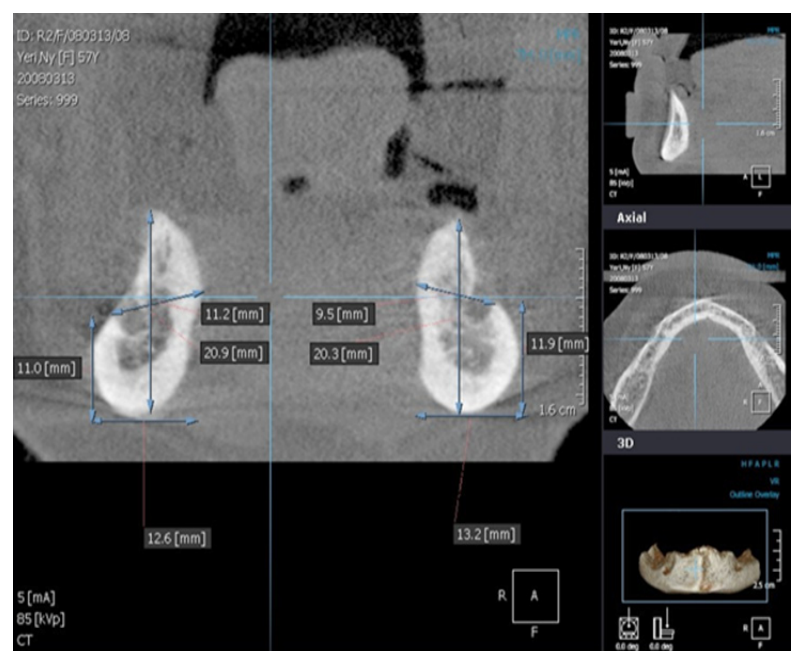

Figure 3. СВCT-3D Image.

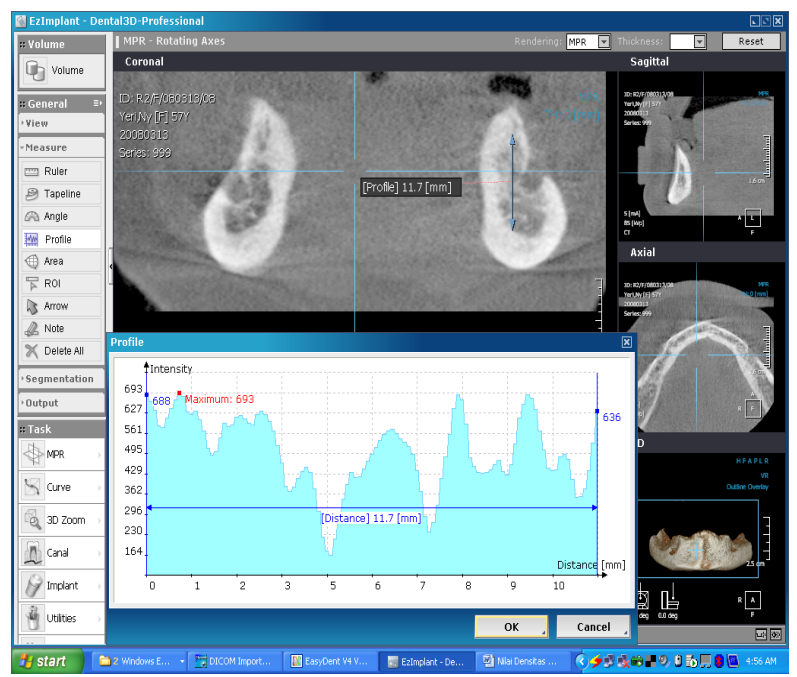

Figure 4. Mandibular bone density graph. 
Table 1. Average value for mandibular bone density and height.

\begin{tabular}{cccc}
\hline No & Age & Average density & Average height \\
\hline 1 & 49 & 504.50 & 41.58 \\
2 & 58 & 416.00 & 25.44 \\
3 & 58 & 407.25 & 40.15 \\
4 & 61 & 438.88 & 30.43 \\
5 & 67 & 368.88 & 26.83 \\
6 & 84 & 323.50 & 13.64 \\
\hline
\end{tabular}

Table 2. Analysis of Correlation among Variables.

\begin{tabular}{cccc}
\hline & Age & $\begin{array}{c}\text { Height } \\
\text { reduction }\end{array}$ & Density \\
\hline $\begin{array}{c}\text { Pearson } \\
\text { Correlation }\end{array}$ & 1 & $-.890\left(^{*}\right)$ & $-.922\left(^{* *}\right)$ \\
Sig. (2-tailed) & & .017 & .009 \\
$\mathrm{~N}$ & 6 & 6 & 6 \\
Pearson & $-.890\left(^{*}\right)$ & 1 & $.815\left(^{*}\right)$ \\
Correlation & .017 & & .048 \\
Sig. (2-tailed) & 6 & 6 & 6 \\
$\mathrm{~N}$ & strong & Very strong \\
Pearson & $-.922\left(^{* *}\right)$ & $.815\left(^{*}\right)$ & 1 \\
Correlation & .009 & .048 & \\
Sig. (2-tailed) & 6 & 6 & 6 \\
$\mathrm{~N}$ & & & \\
& Very strong & strong & \\
\hline
\end{tabular}

minutes the result can be observed in the monitor.

(3) Measuring of the size of the mandibular bone density in mental forament. CT 3D radiograph can be manipulated by rotating around $x$ axis (axial), $y$ axis (sagittal), and $z$ (coronal) to show structures from various angles according to the need. In this study, the mandibular density measurement is performed by showing image in coronal section. The number of parameters absorbed by the bone is stated in Hounsfileld Unit ( $\mathrm{HoU}$ ) (4) Measuring mandibular bone height in mental foramen region. (5) Record results. (6) Analyzing data statistically using correlation analysis.

Instruments and Materials: (1) Dental unit; (2) Dental mirror, explorer, tweezers, mask and gloves. (3) Picasso Trio Instrument (EPX Impla, Impla 0165906, Korea).

\section{Examination form.}

Imaging result measurement

Imanging result using CBCT-3D, in coronal section of right and left mental foramen region.

\section{Data analysis}

The method used to analyze interrelationship among variables is Pearson's Bivariate Correlation. ${ }^{18}$

To reveal the correlation among variables, two variable statistic correlation classification of Guilford is used ${ }^{18}$

\begin{tabular}{ll}
\hline $\begin{array}{l}\text { Two variables statistical } \\
\text { correlation value }\end{array}$ & \multicolumn{1}{c}{ Note } \\
\hline$<0,2$ & $\begin{array}{l}\text { No correlation between the two } \\
\text { variables } \\
\text { Weak correlation between the } \\
\text { two variables } \\
0,2-0,4\end{array}$ \\
$\begin{array}{l}\text { Medium correlation between } \\
\text { the two variables }\end{array}$ \\
$0,4-0,7$ & $\begin{array}{l}\text { Strong correlation between the } \\
\text { two variables } \\
\text { Very strong correlation between } \\
\text { t two variables }\end{array}$ \\
\hline
\end{tabular}

\section{Study location and time}

Thestudy was performed at theProsthodontic Department and Radiology Department of RSGM FKG UNPAD. The study was performed in the period of January 2008 to March 2008.

\section{RESULTS}

The study data were collected from six female edentulous patients who are in menopause period. The data consists of images taken using Picasso Trio instrument. The height and density measurement was performed in the left and right mental foramen region in coronal section. The bone height was calculated based on the formulation of Wical and Swooope. ${ }^{16}$

\section{DISCUSSION}

This study is aimed at observing correlation between age and density and mandibular bone 
height. From table 2 it is apparent that the increased age has a strong correlation with decreased density with a correlation value of $(r)$ 0.922 with $a=0.009$. This means that the older the patient the lower the bone density. This conclusion is in line with the conclusion from the study conducted by Solar ${ }^{12}$ to mandibular bones of 25 cadavers that show the higher the age, the lower the bone mineral content. The bone mass density is affected by several factors. The factors include age, nutrition, heredity, physical activities, life style and hormone condition.

Women experience faster bone mass reduction compared to men due to the menopause process. In menopause period, bone mass reduction occurs due to reduced estrogen level. Estrogen plays the role in regulating vitamin D activities that help calcium absorption process in the intestines and calcium reabsorption in the kidney and synthesizes and secretes factors that affect remodelling process. The situation leads to reduced skeletal bone density, including mandibular bones. Several studies stated that skeletal bone mineral loss affects jaw bone density. Studies performed by Anggraini ${ }^{7}$ and $\mathrm{Xie}^{8}$ show that in menopause women, osteoporosis is found in lumbal and femur bones accompanied by thinning of mandible angulus. Kusdhany ${ }^{9}$ in his study concluded that lumbal and femur osteoporosis in post menopause women is also accompanied by osteoporosis in mandibular bone.

The results of the study in six female edentulous patients who are in menopause period show that the lower the mandible density, the lower the mandibular bone height. The reduced density and bone height have strong correlation with a correlation value $(r)$ of 0.815 and $a=0.048$. This study supports the results of a study done by Kribbs $^{19}$ that concluded that there is a significant correlation between alveolar ridge height and mandibular bone mass.

The reduction of mandibular bone density causes reduced mandibular bone height so that changes in form and size of mandible are observed. This is a skeletal adaptation process to function. This condition is in line with Wolff law which implies that bone will adapt to the load applied to it. ${ }^{20}$

Increased age causes reduction in bone height. In this study, the correlation value ( $r$ ) between age and bone height reduction is -0.890 and $a=0.017$. A study by Hirai ${ }^{2}$ to 44 edentulous patients who suffer from osteoporosis stated that the older someone, the lower the jaw bone height and that the osteoporosis severity level increased progressively with aging process.

The results of this study are in line with the literature review and studies that show a correlation between bone quality and quantity reduction and age. In aging process, the body slowly experiences reduced ability in repairing and maintaining its normal structure and function. ${ }^{14} \mathrm{In}$ aging process, there is a deficit between resorption and formation because of inadequate osteoblast provision. With increased age, bone experience thinning and becomes more porous, about 4$10 \%$ since the age of 40 years. After the age of 40 years, the thinning process becomes less, i.e. $3 \%$ per decade and increased to $9 \%$ per decade in menopause women. ${ }^{20}$

The alveolar bone resorption usually occurs in elderly women and men. The resorption speed is affected by the presence of osteoporosis. The osteoporosis condition usually overlaps with bone loss caused by aging process. This bone loss can be prevented or slowed but there is no therapy that can repair bone loss. The changes seen in jaw bone is a representative of the general condition of the skeletal bone. The cortical bone thinning and continuous reduction of trabecular bone may cause the bone to be fragile. ${ }^{14}$ According to Atwood ${ }^{21}$, the factors causing resorption are multifactorial. Those include anatomical, biological, functional dan prosthetic factors. Anatomical factor includes the anatomy of alveolar ridge and bone mass that affect resorption speed. The biological factor is as mentioned above, that is the height of residual ridge is determined by age, hormonal influence, nutrition, et cetera. Meanwhile, the functional force factor include frequency, intensity, duration and the direction of forces applied to the bone that can be produced by cell biological activities resulting in bone formation and resorption, depending on the individual immunity.

According to Baxter ${ }^{13}$ in women who have experienced menopause, the decreased bone quality will affect the clinical prognosis in prosthodontic treatment. Hock ${ }^{14}$ stated that patients with osteoporosis needs new denture more often compared to patients without osteoporosis. 
Based on a study done by Tallgren ${ }^{15}$ in full denture users, the ratio of resorption between the anterior part of lower jaw and anterior part of upper jaw is $4: 1$. Wyatt ${ }^{22}$ in his article stated that denture affects alveolar bone resorption. According to Jahangiri23, the mechanical factors of the artificial denture affect the cellular components of alveolar bone regeneration.

Prosthodontic treatment is aimed at maintaining residual tissue health. In elderly patients, the quality and quantity of the bone will be reduced and this makes the ability of the bone to resist the load less. Therefore, these patients need special attention, especially for patients with full artificial denture. The problem of occlusion load becomes important to be observed. Load applied to the bone should be made as minimum as possible. This can be achieved by ${ }^{24}$ : (1) Making impression on the tissue with less pressured position; (2) The expansion of prosthetic base should be made so that it gets maximum support and the load is distributed in the widest area possible; (3) Pressure on the tissue that are caused by food bolus can be lessened by reducing the number of teeth and reducing artificial tooth width; (4) Pressure on anterior region can be lessened eliminating contact in this region during centric relation and by avoiding biting on the anterior region; (5) Monitoring every 6 months should be performed to update medical record both for dental and general condition. In each monitoring visit, the examination on the condition of the denture is absolutely necessary. For patients who are wearing partial removable denture, periodontal health evaluation should always be done. If necessary, relining or rebasing should be conducted.

From this study it is proven that with the increased age, the density and height of the mandibular bone will be reduced. The bone reduction caused by resorption process is something that cannot be avoided because it is a natural process. A careful examination at the time the prosthodontic treatment is performed will bring good prognosis for long term prosthetic denture use.

\section{CONCLUSION AND SUGGESTION}

This study was performed to six female edentulous patients in menopause period on the mandibular bone in mental foramen region. This study has proven that the older the age, the lower the mandibular bone height. The quality and quantity of bone in elderly patient will keep reducing along with the older age leading to reduced bone ability to resist load. Therefore, in making artificial denture for elderly patients, a special attention should be given so that the load received by the jaw bone can be made as minimum as possible, the load is distributed in the widest area possible, and the occlusion and articulation aspects should be attended accompanied with routine monitoring. Further study with bigger sample size is needed, based on age group and gender, to get data with better validity and reliability.

\section{REFERENCES}

1. Indonesia Health Profile 2005. [cited 2008 Jan 10] Available from:http://www.depkes.go.id.

2. Hirai T, Ishijima T, Hashikawa Y, Yajima T. Osteoporosis and reduction of residual ridge in edentulous patiens. J Prosthet Dent 1993;69(1):49-56.

3. Biben Ahmad. Pengaruh suplementasi diet tempe formula terhadap formasi dan resorbsi tulang pada wanita pra- dan pasca menopause. disertasi. Bandung: Universitas Padjadjaran; 2001.

4. Bone mineral density. Osteoporosis Health Center. [cited 2007 Sept 29] Available from: http://www.com/osteoporosis.

5. Kusdhany SL. Penentuan indeks densitas tulang mandibula perempuan pasca menopause dengan memperhatikan beberapa faktor resiko terjadinya osteoporosis. Disertasi. Jakarta: Universitas Indonesia; 2003.

6. Klemetti E. A review of residual ridge resorption and bone density. J Prosthet Dent 1996;75(5):512-4.

7. Anggraini $\mathrm{W}$. Hubungan osteoporosis dengan bentuk antomi mandibula tidak bergigi wanita pasca-menopause. M.I. Kedokteran Gigi Usakti. 1999;(Edisi khusus FORIL IV):448-9.

8. Xie Q, Wolf J, Tilvis R, Ainamo A. Resorption of mandibular canal wall in edentulous aged population. J Prosthet Dent 1997;77(6):596600.

9. Kusdhany L, Ichramsyah AR, Bambang S, 
Irawati I, Chaidar M. Validitas indeks densitas tulang mandibula postur-P dalam memprediksi densitas tulang perempuan pascamenopause. Indonesia J Dentistry 2005;12(3):113-6.

10. Klemetti E, Vainio P. Effect of bone mineral density in skeleton and mandible on extraction of teeth and clinical alveolar height. J Prosthet Dent 1993;69(1):21-5.

11. Ortman LF, Haussmann E, Dunford G. Skeletal osteopenia and residual ridge resorption. J Prosthet Dent 1989;61(3):321-5.

12. Solar P, Christian W. Sex-related differences in bone mineral density of atrophic mandibles. $J$ Prosthet Dent 1994;71(3):345-9.

13. Baxter C. Relationship of osteoporosis to excessive residual ridge resorption. $J$ Prosthet Dent 1981. 46(2): 123-5.

14. Hock J. Aging of the bone tissue. In: Pedersen $\mathrm{PH}$, Loe H. Geriatric dentistry $2^{\text {nd }}$ ed. Copenhagen Munksgaard. 1996. p. 68-90.

15. Tallgren $A$. The continuing reduction of residual alveolar ridge in complete denture wearers: mixed longitudinal study covering 25 years. J Prosthet Dent 2003;89(5):427-35.

16. Wical KE, Swoope CC. Studies of residual ridge resorption. Part I: Use of panoramic radiograph for evaluation and classification of mandibular resorption. J Prosthet Dent 1974;32(1):7-12.

17. Tsiklakis K, Syriopoulus K, Stamatakis $\mathrm{HC}$. Radiographic examination of the temporomandibular joint using cone beam computed tomography. J Dentomaxillofacial Radiology 2004;33:197.

18. Zanbar Ahmad S. Ilmu statistika: Pendekatan dan aplikatif SPSS. Rekayasa Sains. 2005. p. 187.

19. Kribbs PJ. Two years changes in mandibular bone mass in an osteoporotic population. J Prosthet Dent 1992;67(6):653-5.

20. Pedersen PH, Loe H, Geriatric Dentisry 1 st ed. Copenhagen Munksgaard. 1986. p. 108-92.

21. Atwood DA. Some clinical factors to rate of resorption of residual ridge. J Prosthet Dent 2001;86(2):119-25

22. Wyatt CL. The effect of prosthodontics treatment on alveolar bone loss: A review of literature. J Prosthet Dent 1998;80:362-6.

23. Jahanggiri L, Devlin $H$, Ting $K$, Nishimura I. Current perspective in residual ridge remodeling and its clinical implication: a review. J Prosthet Dent. 1998;80(2):224-37.

24. Sratton JR, Johnson DL. Fundamental of removable prosthodontics. Quintenssence Co.Inc.1980. p 30-2. 